\title{
The Role of Multinationality and Transfer Pricing on the Effect of Good Corporate Governance (GCG) and Company' s Performance in Tax Avoidance
}

\author{
Trisna Nugraha Pamungkas* and Bagus Nurcahyo \\ Department of Accounting, Faculty of Economics, Gunadarma University, Indonesia \\ "Corresponding author: Trisna Nugraha Pamungkas, Department of Accounting, Faculty of Economics, Gunadarma University, Indonesia, Tel: +6285886868575; E- \\ mail: trisna.nugraha.p@gmail.com
}

Rec date: Sep 06, 2018; Acc date: Oct 16, 2018; Pub date: Oct 22, 2018

Copyright: (c) 2018 Pamungkas TN et al. This is an open-access article distributed under the terms of the Creative Commons Attribution License, which permits unrestricted use, distribution, and reproduction in any medium, provided the original author and source are credited.

\begin{abstract}
This study aims to analyze the role of multinationality and Transfer Pricing on the effect of Good Corporate Governance (GCG) and Company's Performance (liquidity, profitability and leverage) on Tax Avoidance by companies listing on the Indonesia Stock Exchange in 2017. Transfer pricing policy is proxied by transactions between affiliated companies and tax avoidance proxied by CETR. The object in this study are the company listed on the Indonesia Stock Exchange in 2017, with the exception of the financial and banking industry. There are 536 companies that have been listed on the IDX during the research period. The difference between this study and previous research are more complex analysis and discussion of transfer pricing policies and the potential for tax avoidance, especially for multinational companies. In addition, researchers included multinationality variables because the data showed that $49 \%$ of listed companies were multinational companies. This research uses path analysis method using SPSS AMOS 22.0 software. GCG Variables and Company's Performance as exogenous variables and Transfer Pricing and Tax Avoidance as endogenous variables.
\end{abstract}

The results of the study concluded that, multinationality affects transfer pricing. The multinationality variable has intervened in the GCG variable towards transfer pricing and the company's performance variables towards transfer pricing. In addition, the transfer pricing policy conducted by the company affects the tax avoidance variable.

Keywords: Good corporate governance (GCG); Company's performance; Multinationality; Transfer pricing; Tax avoidance

\section{Introduction}

The existence of economic globalization makes domestic tax policy increasingly a source of friction. These conditions gave rise to various economic challenges and the taxation system that accompanied them, including Indonesia. According to Tomohara the Government is required to protect or expand the tax base in each jurisdiction, when concerns about the effects of barriers in global trade, tax policies can lead to conditionality in the existing business climate [1]. The transfer price problem is one method to divert income which erodes the tax base in jurisdiction. Manipulating transfer prices in intra-company transactions allows income to move between multinational affiliates and makes tax evasion possible. According to Kurniasih and Sari tax minimization efforts that do not violate the law are generally called tax planning that has scope on tax planning that does not violate the law, also called tax avoidance, which is an implementation of efficiency for the company in a legal way due to imperfections in the Tax Law [2].

Transfer pricing is a classic problem in the world of taxation, especially for developing countries. Transfer pricing problems in Indonesia occur when each cross-border transaction, Indonesian taxation rights are always in an unfavorable position, so there is a potential loss for state revenue. These multinational companies use transfer pricing practices to minimize their tax payments. Although it looks legal, these methods are considered immoral [3].
In general, transfer pricing is a company policy in determining the price of transfer of a transaction, whether it is goods, services, intangible assets, or financial transactions carried out by the company. Eden termed transfer pricing manipulation with an activity to increase costs or lower bills that aim to reduce the amount of tax owed [4]. There are two transaction groups in transfer pricing, namely intracompany and inter-company transfer pricing. Intra-company transfer pricing is an inter-division transfer pricing within a company. While inter-company transfer pricing is a transfer pricing between two companies that have a special relationship.

According to Setiawan the notion of transfer pricing is often connoted with something that is not good, even as an act of abuse of transfer pricing [3]. Abuse of transfer pricing can not only be done in a country that has a lower tax rate (tax heaven countries) but can also be done in companies in a group in countries with higher tax rates as long as companies in the country are experiencing losses or there are many taxation loopholes that can be used in the country. For companies, transfer pricing practices are expected to increase company performance [5].

For companies, tax is a burden that will reduce net income, so the company tries to keep the tax payment to a minimum. The company's efforts to minimize its tax burden are called tax planning. Tax planning that is done legally and does not conflict with tax regulations is called tax avoidance. The methods and techniques used are utilizing weaknesses (gray areas) contained in the laws and tax regulations themselves, to minimize the amount of tax owed. The amount of tax 
avoidance can be seen from the comparison between cash spent on tax costs and profit before tax (Cash Effective Tax Rate/CETR) [6].

Several studies related to the topic of company's performance, corporate governance, transfer pricing, and tax avoidance show different results. Kurniasih and Sari's research shows that one of the variables of company performance (leverage) and corporate governance does not affect tax avoidance [2]. Meanwhile, Prakosa's research shows that the composition variable of the board of commissioners as one of the corporate governance proxies has a significant effect on tax avoidance [7]. Different results are also shown by Maharani and Suardana's study which states that the proportion of independent commissioners and audit committees as corporate governance proxy has a significant effect on tax avoidance, while institutional ownership has no effect [8]. Based on the description above, the researchers want to re-examine the topic of transfer pricing and tax avoidance in Indonesia with consideration of several policy updates issued by the government.

\section{Theoretical Framework and Hypothesis Development}

\section{Theory of policy and implementation}

According to Winarno the term policy in everyday life is used to designate an activity that has a different purpose [9]. Basically, public policy not only emphasizes what the government proposes, but also includes the direction of action and what is done by the government. This is in accordance with public policy according to Thomas R. Dye, public policy is defined as an action chosen by the government to be done or not done (whatever government choose to do or not to do).

Implementation is the provision of means to implement something that has an impact or effect on something. Implementation is also the actions taken by the government to achieve the goals set in a policy decision. The government in making policy must first examine whether the policy can have a bad or no impact on the community. It is intended that a policy does not conflict with the community especially to the detriment of society.

Fiscal policy is an adjustment in government revenue and expenditure to achieve better economic stability and desired economic development practices. Fiscal policy based on narrow understanding can be called a tax policy. As is known, tax basically has two functions, namely budgeting and regularity. Tax policy is a fiscal policy in a narrow sense, namely a policy relating to the determination of who will be taxed, how to calculate the amount of tax that must be paid and how the procedure for payment of tax payable.

\section{Special relationship}

Some countries can determine whether a transaction occurs naturally or not without seeing who is transacting. There are also those who see who transacts from what is commonly referred to as the quality approach. Based on this approach, if there is an independent party without a significant relationship that can influence the policy, the price or the reward for deviating from the price that can be accepted in the free market. So, regardless of the price or return that will be received (by the tax administration) and considered as a fair price, if there is a relationship that can affect the administration can recalculate the price considered for the transfer of the service.

According to Darussalam the special relationship scheme can be described in Figure 1 [5]:

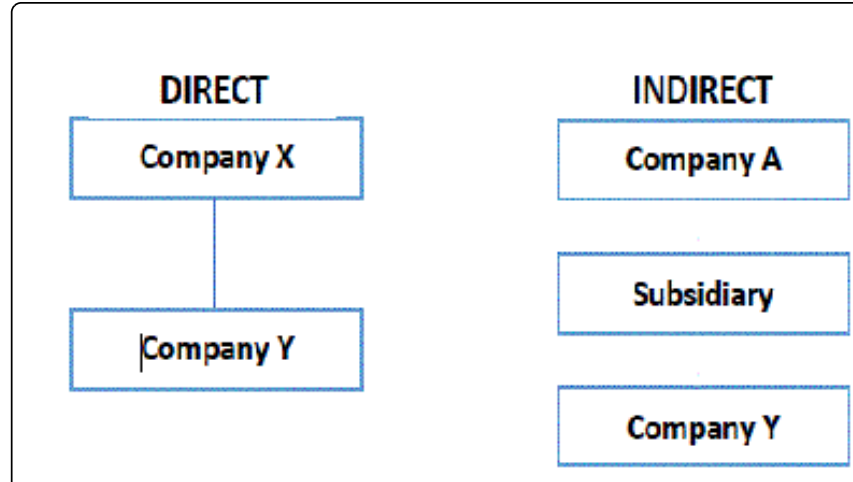

Figure 1: Special relationship scheme.

\section{Transfer pricing and tax avoidance}

Transfer pricing is a company policy in determining the price of transfer of a transaction whether it is goods, services, intangible assets, or even financial transactions carried out by the company. There are two transaction groups in transfer pricing, namely intra-company and inter-company transfer pricing. Intra-company transfer pricing is a transfer pricing between divisions within a company. While intercompany transfer pricing is a transfer pricing between two companies that have a special relationship. The transaction itself can be done in one country (domestic transfer pricing), as well as with different countries (international transfer pricing). According to Wirakusuma and Cindrawati, Transfer pricing is the price contained in each product or service from a division that is transferred to another division within the same company or between companies that have a special relationship [10]. Darussalam termed transfer pricing manipulation with an activity to increase costs or lower bills that aim to reduce the amount of tax owed [5].

Feinschreiber and Darussalam proposed transfer pricing in the perspective of taxation, is a price policy in transactions conducted by parties that have a special relationship [5,11]. It states that transfer pricing is the pricing of business transactions between the associated parties. In Indonesia alone, transactions involving related parties are regulated in several rules. In PSAK No. 7 concerning Related Party Disclosures, it is explained that the related parties are persons or entities related to entities that prepare their financial statements (in this Statement referred to as "reporting entities"). The Director General of Taxes Regulation Per 32/PJ/2011, still uses the term special relationship and is defined as the relationship between taxpayers and other parties. Relationships with the parties involved are normal activities in trade or business. However, in the tax provisions, the transaction of an affiliated company or having a special relationship becomes a concern when it is suspected that it aims to avoid taxation [12].

The definition of tax according to UU No.28 of 2007 concerning KUP is as follows: "Tax is a compulsory contribution to the state owed by an individual or a compelling body based on the law, by not getting direct compensation and being used for the purposes of the State for the magnitude of people's prosperity. The company's management efforts to obtain the expected profit through the implementation of tax management, one of which is through tax avoidance, namely reducing the amount of tax in a way that does not violate tax laws. Tax avoidance can also be defined as a part of a tax management strategy 
that is not prohibited in tax laws. According to Rego, tax avoidance is the use of tax planning methods to legally reduce the income tax paid [13]. However, Desai and Dharmapala see tax evasion as an abuse of tax shelters [14].

Tax avoidance carried out illegally is tax evasion or can also be considered tax evasion, namely tax evasion which is not permitted in taxation laws and regulations. According to Prebble and Prebble, differences in tax avoidance and tax evasion are that tax evasion is illegal, consisting of intentional violations or circumvention of applicable tax regulations to minimize tax liability [15]. From these definitions it can be concluded that tax avoidance is essentially a way to reduce corporate tax burden by utilizing weaknesses in the applicable tax laws, so that this method cannot be considered illegal.

\section{Hypothesis development}

The number of companies that conduct tax evasion proves that corporate governance has not been fully carried out by public companies in Indonesia [8]. Agency theory says that shareholders or principals want managers or agents to act in accordance with the interests of shareholders, namely increasing profits and cost efficiency including tax costs [15]. For companies, tax is a burden that will reduce net income, so the company tries to keep the tax payment to a minimum. Tax avoidance is defined as every effort made to reduce the tax burden [16].

The company's efforts to minimize its tax burden are called tax planning. Tax planning that is done legally and does not conflict with tax regulations is called tax avoidance. There are several policies carried out in this regard, one of which is through the transfer pricing policy. This is where the role of corporate governance is expected to control the consequences of the agency's problems on tax avoidance $[14,17]$.

H1: Good corporate governance (GCG) affects the transfer pricing policy: Research conducted by Richardson et al. found a positive relationship between income before tax and the applicable tax rate (ETR) $[18,19]$. Companies that have the advantage are more able to adjust the transfer price to reduce (increase) profits in high taxes (low taxes). For example, companies such as Apple, Google and Microsoft have been able to find benefits from low taxes and increased spending taxes (such as royalty payments) and how companies with high taxes reduce taxable profits $[18,19]$.

According to Tomohara the ratios that are often used in an attempt to analyze and interpret financial statements are as follows: (1) Liquidity Ratio, including current ratio, Quick ratio, and cash ratio, (2) Leverage Ratio, including total debt to total assets, and total debt to equity, (3) Profitability Ratios, including economic rentability (Return on Assets \& Return on Equity), and operating profit margin. The financial statements are basically the results of accounting activities. The results of these activities generally have limitations and are arranged based on rules that are standard and generally not fully understood by those who understand accounting [20].

Liquidity according to Gitman et al. is showing the ability of companies to meet short-term financial obligations just in time or the ability of companies to provide cash or cash equivalents aimed at the size of current assets, namely assets that are easily converted into cash which includes cash, securities, receivables, and inventory. Company liquidity is often measured using a current ratio [21]. The current ratio is calculated by dividing current assets with current debt. The leverage ratio is a ratio that shows some part of the overall capital and funds spent on debt. In Muqorobin and Nasir's research, leverage ratio is proxied through Debt to Equity. Profitability is the company's ability to generate profits or profits for one year [20].

H2: The company's performance affects the transfer pricing policy: Tax planning for a multinational operation is a very complex job, but on the other hand it contains aspects that are vital for international business. Multinational companies are companies that operate (produce and sell goods or services) in more than one country. There are two aspects of ownership that need to be considered, namely ownership by an outside party and ownership by an internal party. Companies with greater international exposure had more opportunities to be involved in tax avoidance activities $[6,13]$. One way of avoiding corporate tax is done by transfer pricing.

According to Handayani and Arfan it was concluded that there was a significant influence between the transactions of affiliated companies on the effective tax rate of the company [12]. A positive relationship between pre-tax income and the applicable tax rate (ETR). Based on data from the Organization for Economic and Development (OECD), $60 \%$ of total trade in the world is indicated to practice transfer pricing. According to Tomohara Policy coordination with selfish governments has the potential to increase not only tax revenues and corporate profits, but also trade volume through the allocation of a more efficient tax burden [1].

H3: Multinationality affects the transfer pricing policy: Pricing decisions among international corporate affiliates have become serious problems. According to Puspita and Harto Tax avoidance is defined as every effort made to reduce the tax burden. According to one step that can be used is through tax planning [16]. Tax planning that is done legally and does not conflict with tax regulations is called tax avoidance.

Several studies have proven that tax management is an activity that can increase company value and provide benefits to shareholders $[5,14]$. Phillips argues that giving compensation plays a role in motivating manager's performance in minimizing the effective tax rate of the company. Desai and Dharmapala examined the effect of tax sheltering and the provision of high compensation for managers $[5,14]$. Multinational companies implement efficient tax planning across group entities, it makes sense that companies with children from foreign sources of income will have incentives and opportunities to engage in tax evasion [13]. In fact, multinational companies use tax planning methods that are globally linked and efficiently reduce group tax obligations.

H4: Good corporate governance (GCG) affects the transfer pricing policy with Multinationality as an intervening variable: Through transfer pricing practices, efforts to minimize tax burden are carried out by diverting income and costs of a company that has a special relationship from one country to another in a country whose tax rates are different. Efforts to minimize the tax burden are carried out by diverting the income and costs of a company that has a special relationship from a country to companies in other countries whose tax rates are different. Tax is a source of income for the country, while for companies the tax is a burden that will reduce net income [2]. Differences in interests of tax authorities who want a large and continuous tax revenue are certainly contrary to the interests of companies that want minimum tax payments. Thus, based on this framework, the fifth hypothesis in this study is as follows.

H5: The company's performance affects the transfer pricing policy with Multinationality as an intervening variable: Tax planning itself as 
a leading part of tax management. Tax management can be defined as the management of the company so that the obligation to fulfill its tax obligations can be carried out correctly and well, with the amount of tax that can be reduced as low as possible to get the expected profit without the element of violation that can later lead to sanctions or fines.

Along with increasing tax rates in several countries, Indonesia through the Ministry of Finance specifically also regulates transfer pricing. Regulation of the Minister of Finance of the Republic of Indonesia (PMK) Number 213/PMK.03/2016 concerning Types of Documents and/or Additional Information Required to be Saved by Taxpayers Who Conduct Transactions with Parties Who Have Special Relationships, and Procedures for Management.

Basically, the transaction of an affiliate company is not prohibited. According to Barker, Asare, and Brickman corporations often acquire other companies to build market excellence in their industries or achieve them through organic growth [22]. Based on demands made on corporate transfer pricing networks are generally associated with increased after-tax profitability from organizations around the world and effective fund movements between sub-entities. The existence of a special relationship or mutually bound between companies allows the engineering of transaction prices outside the fair price or market price. This unreasonable price is the spotlight of the government, especially the director general of taxation because the price is usually intended to avoid taxes [12]. It was also stated that based on the findings and conclusions of the Government Accountability Officer (GAO), multinational companies use their foreign activities or between countries to reduce the tax burden.

Types of affiliate transactions that are prone to transfer pricing practices include payment of services, interest, sale and purchase of goods, royalties, transfer of property, and transactions with residents of tax heaven countries. Effective tax rates are a comparison between the tax burden paid by companies with pre-tax income [12].

\section{Research framework}

Based on the development of hypotheses that have been described previously, the conceptual framework of this research is Described in the below Figure 2:

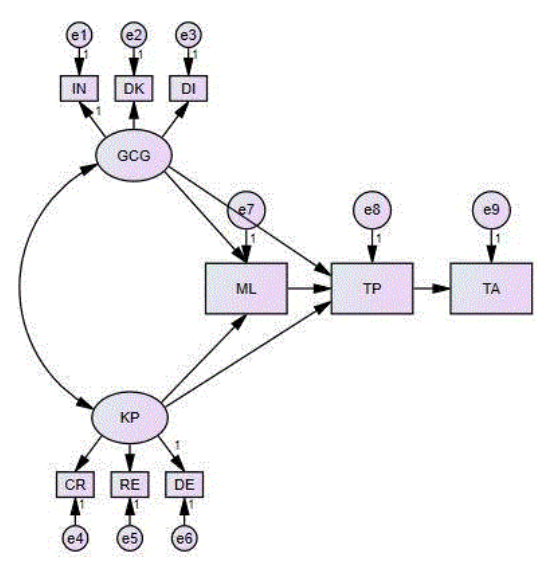

Figure 2: Research framework.

\section{Research Methods}

\section{Research design}

This research is included in quantitative research. This research is associative and uses a causal relationship, which is research that asks the relationship between two or more variables and is causal. This study makes companies listed on the Indonesia Stock Exchange in 2017 as the object under study. The data used in this research is secondary data. The data is in the form of annual reports, financial reports, and summaries of financial summaries of the Indonesia Capital Market Directory (ICMD) in the $2016-2017$ period. The data is obtained from the Indonesia Stock Exchange website (www.idx.co.id), The Indonesia Capital Market Instutie (TICMI) (www.ticmi.co.id) and the official website of the company that is used as a sample.

\section{Population and sample}

The population used in this study are all companies listed on the Indonesia Stock Exchange in 2017. There are 536 (five hundred thirtysix) companies that have been listed on the IDX during the study period.

Determination of the sample to be examined is done by purposive sampling method. According to Supardi (2005) the purposive sampling method is a non-probability sampling technique that is of higher quality and is the development or refinement of previous methods, where researchers have made boundaries based on the criteria to be sampled in the study. The criteria used are as follows:

- Companies that have been listed on the Indonesia Stock Exchange (IDX) in 2017.

- Companies that have published audited financial statements in 2016 and 2017.

- Companies that have published annual reports in 2016 and 2017.

- Companies that have sufficient data needed for research.

- Companies other than the financial and banking industries. This is due to the existence of a special regulation for the industry which allows to influence the proxy of the company's performance.

\section{Variable and measurement}

1. Good corporate governance (GCG): Organization for economic cooperation and development (OECD, 2004), defines it as a system used to direct and control the business activities of a company. According to the Forum for Corporate Governance in Indonesia (FCGI, 2004), corporate governance is a set of rules that establishes the relationship between shareholders, management, creditors, government employees and other internal and external stakeholders in relation to their rights and obligations, or in words another system that directs and controls the company. From these definitions it can be concluded that corporate governance is essentially a system and set of rules that regulate the relationship between shareholders, board of commissioners and board of directors so that the performance of the company is carried out effectively, efficiently, transparently and accountably in order to achieve organizational goals and avoid fraud that conducted by company management. Besides that, it can also produce accountable financial statements that are useful for its users to make decisions. In this study, researchers used a component of the GCG mechanism in the form of institutional ownership, composition of the board of commissioners, and independent commissioners to proximate the Good Corporate Governance variable. 
2. Company's performance: Financial performance is the result achieved from financial inputs that have been used to produce output [20]. According to Agnes (2001) the ratios that are often used in an attempt to analyze and interpret financial statements are as follows: (1) Liquidity Ratio, including current ratio, quick ratio, and cash ratio, (2) Leverage Ratio, including total debt to total assets, and total debt to equity, (3) Profitability Ratios, including economic rentability (Return on Assets \& Return on Equity), and operating profit margin.

This study uses three measures of financial ratios as a proxy of company performance. The first financial ratio is the liquidity ratio measured through the current ratio.

$$
\text { Current ratio }=\frac{\text { Current Asset }}{\text { Current Liability }} \times 100 \%
$$

In line with Muqorrobin and Nasir, this study uses Debt to Equity Ratio as a proxy of leverage [20].

$$
\text { Debt to Equity ratio }=\frac{\text { Total Liability }}{\text { Total Equity }} \times 100 \%
$$

The most common ratio used to measure profitability is Return on Equity (ROE) [23]. This research itself uses ROE as a proxy of profitability ratios. Return on Equity (ROE) can be formulated as follows:

$$
\text { Return On Equity }=\frac{\text { Net Profit }}{\text { Total Equity }} \times 100 \%
$$

3. Multinationality: Multinational companies are companies that operate (produce and sell goods or services) in more than one country. According to Setiawan there are two aspects of ownership that need to be considered, namely ownership by outsiders and ownership by insiders [3]. The insider is the owner who owns shares and is part of the manager of the company. Whereas the so-called external parties are international/multinational companies that have shares of more than $50 \%$ (fifty percent) in subsidiaries (branches) operating in Indonesia. Therefore, the multinationality variable in this study uses a dummy variable to determine whether a company is said to be multinational or not. When a company operates (produces and sells goods or services) in more than one country or shares more than $50 \%$ by a multinational company, then it is stated in 1 (one) and so with the opposite condition will be stated with 0 (zero).

4. Transfer pricing: Transfer pricing is a company policy in determining the price of transfer of a transaction whether it is goods, services, intangible assets, or even financial transactions carried out by the company. Darussalam and Sepriadi termed transfer pricing manipulation with an activity to increase costs or lower bills that aim to reduce the amount of tax owed [5]. Related party transactions are defined based on PSAK No. 7 (2009), which is a transfer of resources, services or liabilities between the reporting entity and related parties, regardless of whether the price is charged. The company sets transfer prices when selling, buying, or sharing resources (tangible or intangible) with its affiliates [5].

Thus, a dummy variable is needed to determine whether or not the transaction between the affiliated companies occurs. When a transaction occurs, the affiliate company will be declared with 1 (one) and when the affiliate transaction does not occur, it will be stated with 0 (zero).

5. Tax avoidance: According to Rego, tax avoidance is the use of tax planning methods to legally reduce the income tax paid [13]. Tax avoidance as one of the active tax resistance efforts, namely all efforts and actions that are directly addressed to the tax authorities and aim to avoid tax. The methods and techniques used are utilizing weaknesses (gray areas) contained in the laws and tax regulations themselves, to minimize the amount of tax owed. The amount of tax avoidance can be seen from the comparison between cash spent on tax costs and profit before tax (Cash Effective Tax Rate/CETR) [6]. Thus, it can be formulated as follows:

\section{Result and Discussion}

\section{Goodness of fit model}

The test of the Goodness of fit model only CMIN (Chi-square), RMSEA, one of the baseline fit (CFI, IFI, NFI, RFI, TLI), one of parsimony fit (PNFI and PCFI), and one of the information theories (AIC, BIC, CAIC, BCC, ECVI, MECVI). Based on the analysis, the goodness of fit indexes are obtained in the Table 1:

\begin{tabular}{|l|l|l|l|}
\hline Goodness of & Result & Cut-off Value & Analysis \\
\hline Fit & & & \\
\hline Chi-Square $(x 2)$ & 0,000 & Expected to be small & Fit \\
\hline RMSEA & 0,055 & $<0,06-0.08$ & Fit \\
\hline CFI & 0,959 & $>0,90$ & Fit \\
\hline PCFI & 0,613 & $>0,50$ & Fit \\
\hline AIC and CAIC & 124,761 & $>$ AIC and CAIC Saturated and & Fit \\
\hline & & Independence Model & \\
\hline
\end{tabular}

Table 1: Goodness of fit analysis.

\section{Hypothesis testing and discussion}

Hypothesis testing is done by analyzing the significant amount of regression weight. This analysis is carried out to show the magnitude of the overall effect, the direct effect and the indirect effects of one variable on another variable.

Based on the results of data processing with the AMOS 22.0 program, the regression weight results obtained which indicate that there are 4 (four) variables obtain $\mathrm{p}$ value $<0.05$ which means there is a significant effect.

Based on the results of the analysis it is known that in testing the first hypothesis (H1a) concluded that Good Corporate Governance (GCG) does not affect the transfer pricing policy carried out by companies. This is evidenced by the Regression Weights test which produces a probability value of $0.131>0.05$ and the output of Standardized Regression Weight is -0.135 . These results are in line with research conducted by Maharani and Suardana which also concludes that good corporate governance with some elements does not affect the transfer pricing policy [8]. Insignificant influence indicates that the Transfer Pricing policy carried out by several companies listing on the Indonesia Stock Exchange is influenced by other factors besides good corporate governance.

Based on data processed by researchers, $59 \%$ of public companies in Indonesia in 2017 indicated conducting transfer pricing policies. Maharani and Suardana's research revealed that the number of companies that do tax avoidance prove that corporate governance has 
not been fully carried out by public companies in Indonesia [8]. The research is in line with the results of this study which indicate that transfer pricing policies are influenced by other factors. In Agency theory, it is explained that shareholders or principals who are GCG components want managers or agents to act in accordance with the interests of shareholders, namely increasing profits and cost efficiency including tax costs $[5,14]$.

Basically, the company as a business actor is required to follow the rules set out by the government, not least in terms of taxation. The resource factor is also an important factor in the company to carry out the transfer pricing policy because not all resources can make transfer pricing documents correctly. Thus, it is closely related to corporate governance and transfer pricing policies by the company.

Testing the second hypothesis $(\mathrm{H} 2 \mathrm{a})$ concludes that the company's performance affects the transfer pricing policy carried out by companies. This is evidenced by the Regression Weights test which produces a probability value of $0.000<0.05$ and the output of Standardized Regression Weight is 0.188 . These results are in line with the research $[13,18]$.

Companies with greater pre-tax profits tend to avoid tax income paid to tax recipients. In the case of transfer pricing, companies that have the advantage are more able to adjust the transfer price to reduce (increase) profits in high taxes (low taxes). This condition is a tax planning policy. The tax planning policy is part of tax management carried out on various purposes. Generally, company profits become important because profit becomes one of the benchmarks in assessing a company's performance. Rego also found that companies with greater pre-tax profits tend to avoid tax income deposited to tax recipients in contrast to companies that have a small profit before tax [13].

The financial statements are basically the final results of accounting activities. The results of these activities generally have limitations and are arranged based on rules that are standard and generally not fully understood by those who understand accounting [20]. In line with the results of the study, to prove the performance of management can use various ways to prove that they are performing well. They can just do a transfer pricing policy which is one of the tax planning policies for the company. If it is done with an established analysis and calculation, it will certainly generate profits for the company. In extreme conditions, transfer pricing can be done to regions or countries categorized as tax haven countries. Although it looks legal, these methods are considered immoral [3].

The testing of the third hypothesis (H3a) concludes that multinationality affects the transfer pricing policy carried out by companies. This is evidenced by the Regression Weights test which produces a probability value of $0.000<0.05$ and the output of Standardized Regression Weight is 0.477 . These results are in line with the research conducted by Rego and Dyreng et al. Handayani and Arfan which concluded that there was a significant relationship of multinationality to transfer pricing policies carried out by companies $[6,12,13]$.

The relationship between transfer pricing and multinationality has long been a global concern. Large global companies also get the spotlight on their policies. Many criticisms have been accused of multinational companies such as Google, Facebook, Yahoo, Starbucks, Apple and Amazon for massive tax evasion through the "double Irish" scheme [22]. Based on data from the Organization for Economic and Development (OECD), $60 \%$ of total trade in the world is indicated by transfer pricing practices. Rego and Dyreng et al. found that companies with greater international exposure had more opportunities to be involved in tax avoidance activities $[6,13]$. One way of avoiding corporate tax is done by transfer pricing.

Due to these conditions, the Indonesian government through the Directorate General of Taxes has actually responded by issuing various questions regarding transfer pricing. In Nurhayati's research it was stated that the Director General of Taxes established the Director General of Taxes Regulation Number PER-69/PJ/2010 dated December 31, 2010 concerning the Transfers Pricing Agreement (APA). In commercial accounting, there is no provision that specifically regulates transfer pricing, but in commercial accounting standards issued by the IAI (Indonesian Accountants Association) can be found statements relating to special relations. PSAK No.7 is a statement of financial accounting standards governing the disclosure of parties that have a special relationship and transactions between the reporting company and related parties.

Testing the fourth hypothesis ( $\mathrm{H} 4 \mathrm{a})$ concludes that Good Corporate Governance (GCG) has an indirect effect on transfer pricing policy with multinationality as an intervening variable. This is evidenced by the Regression Weights test which produces a probability value of $0.024<0.05$ and the output of Standardized Regression Weight is -0.135 . Thus, it is proven that multinationality variables can be said to be intervening variables. These results are in line with the research conducted by Rego [13].

Unlike the testing in the first hypothesis, the Good Corporate Governance (GCG) variable indirectly influences the transfer pricing policy with multinationality as an intervening variable. Here it is proven that multinationality intervenes in the influence of corporate governance on its tax policy, especially transfer pricing policy. In the research of Rego and Hanlon et al. it is stated that multinational companies implement efficient tax planning across group entities, it makes sense that companies with children from foreign sources of income will have incentives and opportunities to be involved in avoidance tax [13]. These results are in line with previous studies, which concluded that multinational companies use tax planning methods that are interrelated globally and efficiently reduce group tax obligations.

Based on the data previously mentioned, 59\% of public companies in Indonesia in 2017 are indicated to carry out a transfer pricing policy. The data is also supported by the research of Maharani and Suardana revealing that the number of companies that do tax avoidance prove that corporate governance has not been fully carried out by public companies in Indonesia [8]. Thus, the results of this study are also in line with the literature described earlier.

Testing the fifth hypothesis (H5a) concludes that company performance does not have an indirect effect on transfer pricing policy with multinationality as an intervening variable. This is evidenced by the Regression Weights test which produces a probability value of $0.054>0.05$ and the output of Standardized Regression Weight is -0.188 . This result is different from testing the direct relationship between company performance and transfer pricing. This means that the multinationality variable intervenes in the relationship, so it becomes insignificant between the two variables.

Interventions can be done through tax management and tax planning. Tax planning itself as a leading part of tax management. Tax planning does not mean as an effort to avoid taxes because if so it is clearly contrary to the applicable tax laws. The multinational company 
can only use transfer pricing lower than arm's length price, for the purpose of streamlining its tax burden or using a higher price than arm's length price for certain purposes.

Tax planning for a multinational operation is a very complex job, but on the other hand it contains aspects that are vital for international business. This condition is also evident in Indonesia, seen in research data that shows that the majority of multinational companies on the Stock Exchange have carried out transfer pricing. The definition of multinational corporation is defined as a company that operates in various countries by opening branches, organizing subsidiaries or contracting agencies. As is known, taxes have an impact on foreign investment decisions on financial structures, the determination of the amount of capital costs, foreign exchange management, working capital management, financial control and of course the company's performance.

Testing the sixth hypothesis (H6a) concludes that there is an influence of the transfer pricing policy on tax avoidance. This is evidenced by the Regression Weights test which produces a probability value of $0.047>0.05$ and the output of the Standardized Regression Weight is 0.096 . Critical Ratio (C.R) value is 1.990 more than the twotailed level significance, namely $1.990>1.960$ which means significant. These results are in line with research [3,12,23,24]. Namely $1.990>1.960$ which means significant. These results are in line with research $[3,12,24]$.

Basically, transactions between affiliated companies are not prohibited. If viewed from a legal and regulatory perspective, it also has its own regulations. However, this is a special relationship or mutually bound between companies that allows the engineering of transaction prices outside the fair price or market price. This unreasonable price is the spotlight of the government, especially the director general of taxation because the price is usually intended to avoid taxes [12,25].

This plan is in the form of pressing as low as possible the amount of tax paid in order to get the expected profit without the element of violation which can later result in sanctions or fines. In the study of Setiawan stated that although the transfer pricing policy is connoted with something that is not good, even as an act of abuse of transfer pricing [3]. However, the policies carried out by the company are legal and do not violate the law, but these methods are considered immoral. The company carries out this policy does not mean without a strong reason. Based on authors demands made on corporate transfer pricing networks are generally associated with increased after-tax profitability from organizations around the world and effective fund movements between sub-entities [26].

Based on the results of testing hypotheses and discussions, the research conclusions are as follows:

Good Corporate Governance (GCG) proxied through institutional ownership, the composition of the board of commissioners and independent commissioners does not have an influence on the transfer pricing policy of companies listed on the IDX in 2017;

Company performance proxied through liquidity ratios, leverage and profitability does not have an influence on the transfer pricing policy of companies listing on the IDX in 2017;

Multinationality has an influence on the transfer pricing policy of companies listed on the IDX in 2017 [27];
Good Corporate Governance (GCG) proxied through institutional ownership, the composition of the board of commissioners and independent commissioners has an influence on the transfer pricing policy of companies listing on the IDX in 2017 with multinationality as an intervening variable;

Company performance proxied through liquidity ratios, leverage and profitability does not have an influence on the transfer pricing policy of companies listing on the Stock Exchange in 2017 with multinationality as an intervening variable;

Transfer pricing policy has the effect of tax avoidance on companies listed on the IDX in 2017.

\section{References}

1. Tomohara A (2004) Inefficiencies of bilateral advanced pricing agreements (BAPA) in taxing multinational companies. Natl Tax J 57: 863-873.

2. Kurniasih T, Sari MMR (2013) Pengaruh Return On Assets, Leverage, Corporate Governance, Ukuran Perusahaan dan Kompensasi Rugi Fiskal Pada Tax Avoidance. Econ Stud Bull 18: 1-84.

3. Setiawan H (2014) Transfer Pricing dan Risikonya Terhadap Penerimaan Negara. PP: 1-11.

4. Eden L (2001) Taxes, transfer pricing, and the multinational enterprise. The Oxford Handbook in International Business, Oxford University Press, pp: 591-619.

5. Darussalam DS (2008) Konsep dan Aplikasi Cross-Border Transfer Pricing untuk Tujuan Perpajakan, Jakarta, Danny Darussalam Tax Center, Indonesia.

6. Dyreng SD, Hanlon M, Maydew EL (2010) The effects of executives on corporate tax avoidance. Account Rev 85: 1163-1189.

7. Prakosa KB (2014) Effect of profitability, family ownership and corporate governance on tax avoidance in Indonesia. Sim-Posium National Accounting XVII Mataram, Lombok.

8. Maharani IGAC, Suardana KA (2014) Effects of Corporate Governance, Profitability, and Executive Characteristics on Manufacturing Company Tax Avoidance. E-J Account 9: 525-539.

9. Winarno B (2007) Public policy: Theory and process. Yogyakarta, Media Pressindo, p: 286.

10. Wirakusuma MG, Cindrawati PM (2011) Effect of Profitability, Solvability, Auditor Reputation, Company Size, Profit and Industrial Types on Inaccuracy of Financial Report Publication at the Indonesia Stock Exchange 2007-2009 Period. Sci A Bus Account.

11. Feinschreiber R (2004) Transfer pricing methods: An applications guide. John Wiley \& Sons, New jersey, US.

12. Handayani D, Arfan T (2014) Effect of Transaction of Affiliated Companies on Effective Tax Rates. Financ Bus Account J7: 11-19.

13. Rego SO (2003) Tax-avoidance activities of US multinational corporations. Contemp Account Res 20: 805-833.

14. Desai MA, Dharmapala D (2006) Corporate tax avoidance and highpowered incentives. J Financ Econ 79: 145-179.

15. Prebble R, Prebble J (2012) Does the Use of General Anti-Avoidance Rules to Combat Tax Avoidance Breach Principles of the Rule of Law? A Comparative Study. Pp:1-26.

16. Puspita SR, Harto P (2014) Effect of Corporate Governance on Tax Avoidance. Diponegoro J Account 3: 1077-1089.

17. Armstrong CS, Blouin JL, Jagolinzer AD, Larcker DF (2015) Corporate governance, incentives, and tax avoidance. J Account Econ 60: 1-17.

18. Richardson G, Taylor G, Lanis R (2013) The impact of board of director oversight characteristics on corporate tax aggressiveness: An empirical analysis. J Account Public Policy 32: 68-88.

19. Boudoukh J, Feldman R, Kogan S, Richardson M (2013) Which news moves stock prices? a textual analysis (No. w18725). National Bureau of Economic Research. NBER Working Paper No. 18725. 
Citation: Pamungkas TN, Nurcahyo B (2018) The Role of Multinationality and Transfer Pricing on the Effect of Good Corporate Governance (GCG) and Company's Performance in Tax Avoidance. J Glob Econ 6: 313. doi:10.4172/2375-4389.1000313

Page 8 of 8

20. Muqorobin A, Nasir M (2009) Application of Financial Ratios as a Measuring Instrument for Corporate Performance. Benefits Manage Bus J 13: $1-13$.

21. Gitman LJ, Juchau R, Flanagan J (2015) Principles of managerial finance. Pearson Higher Education AU. Addison Wesley, Toronto.

22. Barker J, Asare K, Brickman S (2017) Transfer Pricing As A Vehicle In Corporate Tax Avoidance. J Appl Bus Res 33: 9-16.

23. Deitiana $T$ (2011) Effect of financial ratios, sales growth and dividends on stock prices. J Bus Account 13: 57-66.

24. Sari DK, Martani D (2010) Ownership Characteristics, Corporate Governance and Tax Aggressiveness. In The 3rd International Account Conf The 2nd Doctoral Colloquium, pp: 1-2.
25. Winata F (2015) Effect of Corporate Governance on Tax Avoidance in Companies Registered on the Indonesia Stock Exchange in 2013. Tax Account Rev 4: 162.

26. Chan KH, Mo PL, Zhou AY (2013) Government ownership, corporate governance and tax aggressiveness: evidence from China. Account Financ 53: 1029-1051.

27. Tandean VA, Winnie (2012) The Effect of Good Corporate Governance on Tax Avoidance: An Empirical Study on Manufacturing Companies Listed in IDX period 2010-2013. Asian J Account Res 1: 28-38. 